\title{
РОЛЬ ИТАЛО-АЛБАНСКОЙ ЦЕРКВИ И ФУНКЦИЯ ВИЗАНТИЙСКОГО ОБРЯДА В КОНСТРУИРОВАНИИ ИДЕНТИЧНОСТИ АРБРЕШЕЙ СИЦИЛИИ
}

Статья посвящена византийскому обряду как одному из ключевых маркеров определения идентичности арбрешской диаспоральной группь, проживающеей на территории Сищилии. В условиях быстрого развития коммуникации, растущей мобильности людей наблюдается ослабление соииальных связей, размывание этнических грании и снижение иенностных ориентиров. Проблема сохранения самобытности арбрешей и укрепления чувства их этнической принадлежности породила насыщенную культурную жизнь. Итало-албанские приходы в течение долгих лет накапливали информацию об истории, традищиях и обычаях своей общины, укрепляли внешние и внутренние связи, благодаря чему между представителями арбрешской диаспоры возникло чувство внутренней сплоченности. Византийский обряд по-прежнему остаётся наиболее устойчивым к трансформации, поскольку местное духовенство отвечает за сохранность религиозной культуры, тесно связанной с социальной средой в целом, а также направляет свою деятельность на культивирование и сохранение арбрешской идентичности. Итало-албанская иерковь представляет значительный институт, который движется к новым формам организачии или изменяет роль существующих, чтобы реагировать на вызовы современного общества. Итало-албанская церковь высоко цеенится своими прихожанами, и все больше воспринимается как религиозный, социальный и культурный институт, ответственный за сохранение ценностей религиозной культуры, тесно связанной с сочииальной средой в изелом.

Ключевые слова: арбреши, Пьяна-дельи-Альбанези, византийский обряд, идентичность, Итало-албанская цеерковь, традиционная культура

Ссылка при цитировании: Сулоева М.A. Роль итало-албанской церкви и функция византийского обряда в конструировании идентичности арбрешей Сицилии // Вестник антропологии, 2021. № 2. С. 44-60.

Албанские диаспоры, проживающие на территории Южной Италии и Сицилии, являются важным объектом этнолингвистических и антропологических исследований, поскольку языковое и культурное взаимодействие арбешей и итальянцев, происходившее в прошлом, продолжается и в настоящее время. Длительное проживание в изоляции от источника традиции способствовало тому, что арбрешские общины на протяжении веков сохраняли свою идентичность, демонстрируя жиз-

Сулоева Марина Александровна - аспирант, Музей антропологии и этнографии имени Петра Великого Российской академии наук (199034 Санкт-Петербург, Университетская наб., 3). Эл. почта: suloevamarina@yandex.ru 
неспособность своей традиционной культуры. Однако быстрое развитие коммуникации, растущая мобильность людей влияют на традиционные модели поведения, наблюдается ослабление социальных отношений, размывание этнических границ и снижение ценностных ориентиров. Мультикультурный характер современных обществ способствовал тому, что самосознание представителей арбрешской общины существенно видоизменилось за последние десятилетия, несмотря на общий язык и историческую память. В процессе адаптации к новым условиям, а также культурного взаимодействия с населением Италии, начался процесс формирования смешанной идентичности, сочетающей в себе как черты представителей доминантной общности, так и собственные этнокультурные особенности.

Объектом настоящего исследования является традиционная культура арбрешей, проживающих на Сицилии в Пьяна-дельи-Альбанези - основном центре компактного расселения албанской диаспоры в этом регионе. Предметом исследования является византийский обряд венчания как один из важнейших составных культурных элементов, формирующих этническую специфику арбрешей и являющихся ключевым условием определения собственной идентичности. Научная проблема исследования заключается в анализе роли Итало-албанской церкви, а также выявлении функций византийского обряда в конструировании идентичности. На данный момент отсутствует комплексное изучение этого феномена как части традиционной культуры арбрешей Сицилии. Необходим анализ его отдельных элементов, выявление особенностей их современного функционирования в условиях глобализационных процессов. Актуальность темы исследования обусловлена не только необходимостью в изучении современных тенденций развития и функционирования традиционной культуры, испытывающей влияние соседней итальянской, но также в анализе роли церковных и социальных институтов в конструировании идентичности изучаемой диаспоральной группы.

Основными методологическими принципами исследования послужили описательный и сравнительно-исторический подходы. Рассматривая обряд венчания как единый текст, имеющий определенную структуру и сложный комплекс различных элементов, каждый из которых выполняет соответствующую функцию, мы применили методы структурного и функционального анализа. Исторический подход позволил проследить возникновение, формирование и дальнейшие пути развития не только обряда, но и самой итало-албанской церкви. Исследовательскую базу работы составили этнографические, искусствоведческие и прочие исследования ученых-предшественников, включенные в научные издания, а также собственные полевые материалы автора, собранные в результате экспедиций на Балканский полуостров и в Южную Италию: Южная Албания (2014-2015 гг.), Пьяна-дельи-Альбанези, Палермо, Сицилия (2016-2020 гг.).

\section{К истории арбрешских поселений}

Присутствие арбрешей на территории Италии насчитывает несколько столетий. Еще в XIV веке между Албанией и Неаполитанским королевством сложились выгодные обеим сторонам военно-политические отношения, благодаря чему многие албанские солдаты, помогавшие королю Неаполя в подавлении восстаний, получили от него в дар земли, на которых были основаны первые арбрешские деревни (Zangari 1940: 52). 
Однако наиболее продолжительный и многочисленный исход албанцев и греков наблюдался с конца XV века, когда после смерти национального героя Георга Кастриоти по прозвищу Скандербег ${ }^{1}$ всё большее число албанских городов и крепостей оказывалось под османским управлением (Арм 1992: 76-78). Население Албании подвергалось преследованиям и массовым убийствам, поэтому с нарастающим давлением османских завоевателей Албанию стали покидать новые группы мигрантов, воспользовавшись тем, что в Калабрии уже были основаны первые колонии (Mastroberti 2008: 149). Миграция населения происходила в основном из южных и центральных районов Албании, а также из Мореи ${ }^{2}$ - области на юге Греции. Прибытие албанских беженцев могло в значительной степени укрепить экономику и демографию малонаселенных районов, поэтому многие из албанцев при одобрении католической церкви получили землю и права от местных феодалов (Emmanuele 1988: 90). Основные регионы, в которые миграция албанцев была наиболее существенной, это Калабрия, Сицилия, Молизе, Кампания, Апулия и Базиликата. Вплоть до первой половины XVIII века переселенцы продолжали основывать новые общины на побережье Южной Италии. В течение всего этого времени и в последующие два столетия албанцы сохраняли свой язык, вероисповедание, этнический костюм, а также прежний, бытовавший до начала переселения эндоэтноним арбреш (apбp. arbëresh).

В отличие от жителей других арбрешских поселений Сицилии, где постепенная языковая ассимиляция и последовавшее за ней утрачивание значимых элементов традиционной культуры привели к изменению маркеров самоидентификации, представители албанской диаспоры, проживающие в Пьяна-дельи-Альбанези, до сих пор выделяют три ключевые составляющие, формирующие их этническую специфику: местный диалект албанского языка, традиционную одежду и византийский обряд (Mandalà 2014: 101). В совокупности эти особенности обеспечивают сохранность и жизнеспособность национальной, этнической и культурной идентичности в условиях глобализационных процессов, поэтому исключение хотя бы одной из них ведет к неизменному утрачиванию осознанного восприятия себя как части отдельного народа.

Для арбрешей византийский обряд является вторым по значимости (после языка) объединяющим фактором, поскольку он формирует представление о собственном происхождении и позволяет осмыслить генетическую связь не только с членами своей общины, но и с представителями других албанских коммун, расположенных на Сицилии, в Калабрии, Базиликате, Апулии, Молизе и др. Кроме того, обряд напоминает об исторических событиях, связанных с эпохой Скандербега, и таким образом становится символом единения албанского народа, воевавшего против турок-мусульман (Parrino 2004: 4).

\section{Краткая история возникновения итало-албанской церкви}

Географическое положение Сицилии во многом обусловило её конфессиональное развитие, поскольку остров оказался на пересечении интересов крупнейших политических сил, веками ведущих борьбу за право господства в Средиземном море.

Многочисленная греческая община основала свои поселения на восточных бе-

\footnotetext{
${ }^{1}$ Георг Кастриоти по прозвищу Скандербег (1405-1468 гг.) - правитель княжества Кастриоти, вождь антиосманского албанского восстания, национальный герой Албании, воспеваемый в народных песнях (Арш 1992: 56-62).

${ }^{2}$ Морея - средневековое название полуострова Пелопоннес.
} 
регах острова еще в VIII-VI веках до н. э. С этого момента история Сицилии была неразрывно связана с греческой культурой. На протяжении следующих шести веков Сицилия являлась провинцией Римской республики. С принятием христианства в качестве государственной религии Римской империи это решение затронуло также Сицилию, и христианство стало стремительно распространяться по всему острову, где до этого преобладала старая религия - греческий античный политеизм и имелись святилища различных божеств. В начале IV века н. э. здесь появились первые христианские общины (Норвич 2018: 41). С 535 года Сицилия была включена в состав Восточной Римской империи в качестве одной из ее провинций, духовная власть Константинополя укрепилась, а вместе с ней - греческая богослужебная традиция. В 737 году все епископские престолы, бывшие в ведении римского папы, вошли в состав Константинопольского Патриархата, отношения между папством и церковными представителями острова были запрещены (Иващенко 1867: 1). С прекращением вмешательства Рима в церковные дела Сицилии главой островной церкви стал местный епископ, позже возведенный в сан митрополита. С этого момента в церковной жизни Сицилии началось главенство греческого языка и восточных обычаев, на юге Италии все калабрийские и апулийские епископы также совершали богослужения только по византийскому обряду (Паче 2019: 20).

B IX веке территорию острова заняли арабы, контроль Константинополя над этими землями был утрачен, Сицилия стала мусульманским эмиратом, а Палермо, получивший название Аль-Мадина, - его столицей. Однако греческая православная община продолжала быть крупнейшей этноконфессиональной группой Сицилии, ей было позволено сохранять свободу вероисповедания, выплачивая ежегодную дань. Веротерпимость арабов позволила сохранить церкви и монастыри (Норвич 2018: 44-45).

С конца XI вплоть до начала XII века шло завоевание Южной Италии выходцами из Нормандии, в результате чего Византия утратила контроль над югом Италии, а Сицилия стала частью Сицилийского королевства, при этом греческий и арабский языки начали постепенно вытесняться развивающимся сицилийским диалектом итальянского языка. В поздний период норманнского расселения в итальянских землях начался процесс католизации населения, римские папы восстановили свою власть над грекоязычными общинами Италии, многие из которых не участвовали в Великом Расколе 1054 года и сохранили общение с Римским престолом. С укреплением Рима в политическом и религиозном плане произошла замена греческих архиереев латинскими, однако привычный византийский обряд сохранился. Норманнские правители основывали новые греческие монастыри и поддерживали уже существовавшие, вместе с этим они поощряли латинскую иммиграцию, что также способствовало проникновению и укреплению римского обряда наряду с греческим.

С падением правления династии норманнов в 1194 году политика последующих правителей Сицилии была направлена на дальнейшую латинизацию местной церкви, начался процесс ассимиляции греческих общин византийского обряда ${ }^{1}$ (Норвич 2015: 134). Однако прибывшие с территории Балканского полуострова во второй половине XV века албанские мигранты, часть из которых исповедовала православие, успешно противостояли данному процессу. Переселенцы признали главенство папы, но сохранили греческий обряд, продолжили поклоняться византийским свя-

${ }^{1} \mathrm{~K} X \mathrm{~V}$ в. процесс латинизации был практически завершен, однако в удаленных горных областях греческие монастыри продолжали существовать вплоть до XVII в. 
тым и вести богослужения на греческом, а позже и на арбрешском языках. С этого периода традиционное название «Итало-греческая церковь» начало постепенно изменяться на «Итало-албанская» (Католическая энциклопедия 2005).

Однако в церковном законодательстве все же была дискриминация приверженцев византийского обряда, их отношения с папским престолом были довольно напряженные. Албанская церковь пережила множество конфликтов с латинским епископатом, поскольку верующие и их православные священники не имели прав и находились под юрисдикцией римской церкви. Латинское окружение привело к тому, что Итало-албанская церковь начала утрачивать свои литургические традиции. В 1734 году в Палермо папой Климентом ХІІ была учреждена духовная семинария, дававшая возможность готовить духовенство по канонам восточной традиции (Роберсон 1999: 68).

В 1742 году папа Бенедикт XIV издал конституцию, в которой были пересмотрены многие положения церковного законодательства, албанцы Сицилии призывались к сохранению своего обряда, но вместе с тем подчёркивалось первенство латинского. Окончательное же равноправие установилось лишь в XIX веке, когда в 1867 году папа Пий IX отказался от преобладания латинского обряда (Роберсон 1999: 69). А в 1937 году папой Пием XI была учреждена епархия ${ }^{1}$ Пьяна-деи-Гречи, подчинявшаяся папе римскому, но не зависимая от иерархов в Палермо⒉ В 1941 году она была переименована в Пьяна-дельи-Альбанези. В состав новой епархии вошли муниципалитеты Пьяна-деи-Гречи и Санта-Кристина-Джелла, получившие территорию от архиепархии Монреале и Палермо, а также византийские ритуальные приходы Меццоюзо, Контесса-Энтеллина и Палаццо-Адриано, выведенные из-под юрисдикции архиепархии Палермо и Монреале, и, наконец, церковь Сан-Николо-деи-Гречи в Палермо. Таким образом, возникла Итало-албанская церковь, совмещающая западный/католический катехизис и главенство папы с восточной литургической традицией. Это единственная из греко-католических церквей, образовавшаяся не путём унии ${ }^{3}$ со святым Престолом, а изначально оставшаяся в сфере влияния Рима во время Великого Раскола 1054 года.

Современная Итало-албанская католическая церковь состоит из двух независимых епархий: Пьяна-дельи-Альбанези (на Сицилии) и Лунгро (в Калабрии), а также монастыря ордена базилиан Гроттаферрата, имеющего статус территориального аббатства и расположенного в Центральной Италии. На епархиальной территории, которая разделена на пятнадцать приходов, также существуют религиозные ордена исповедующих восточный обряд. Однако со временем некоторые из приходов византийского обряда были переданы немногочисленным католикам латинского обряда, проживающим в арбрешских коммунах ${ }^{4}$.

${ }^{1}$ Епархия - церковно-административная территориальная единица во главе с архиереем (епископом) (Католическая эничиклопедия 2002).

${ }^{2}$ Речь идет о таком редком явлении, как прямое подчинение Римскому престолу без посредничества других церковных институтов.

${ }^{3}$ Уния - объединение Римско-католической церкви с одной из восточных на условиях признания последней католического вероучения и догматики, но при сохранении своего обряда, богослужебного календаря и разрешения на брак для белого духовенства (Католическая энциклопедия 2002).

${ }^{4}$ На протяжении десятилетий между «латинянами» и «греками» наблюдались споры и противостояния. Сегодня из пятнадцати приходов византийского обряда пять переданы верующим латинского обряда. Община Санта-Кристина-Джеллы не так давно отказалась от греческой церковной традиции в пользу латинской, однако византийский обряд используется в некоторых особых случаях. В Пьяна-дельи-Альбанези церковь Св. Вита, также изначально принадлежавшая верующим византийского обряда, в 1596 году была передана латино-католикам (ПМА 2). 
На сегодняшний день епархия Пьяна-дельи-Альбанези является результатом борьбы за национально-религиозное сохранение арбрешской диаспоры. Следование византийскому обряду представляет одну из характерных этнокультурных особенностей албанской диаспоральной группы и демонстрирует привязанность арбрешей к культурному наследию своей прародины и историческую преемственность традиций, восходящих ко времени Скандербега.

\section{К вопросу о формировании идентичности арбрешей и роли византийского обряда}

Особенность географического положения Пьяна-дельи-Альбанези явилась причиной того, что на протяжении нескольких веков это арбрешское поселение продолжало оставаться изолированным от остальной части Сицилии, а его жители передавали из поколения в поколение свои обычаи и традиции в «законсервированном» виде. Долгое время сицилийцы оставались индифферентными по отношению к албанским переселенцам, которые, в свою очередь, желали сохранить этническую самобытность, что также замедлило процесс взаимопроникновения культурных элементов. Однако период после Второй мировой войны был отмечен интенсивной эмиграцией в другие страны, оттоком рабочей силы из сельской местности, введением обязательного образования, получаемого в итальянских учебных заведениях (преподавание в которых ведется на итальянском языке), распространением средств массовой информации, а также модернизационными процессами. Все это привело к тому, что сопротивление арбрешей влиянию доминантной культуры с течением времени постепенно начало ослабевать, при этом усилился процесс социокультурной дезинтеграции внутри их диаспоральной группы. В новых жизненных реалиях современные арбреши часто сталкиваются с проблемой определения этнической принадлежности, поскольку в процессе адаптации к новым условиям и взаимодействия с сицилийцами, начался процесс формирования смешанной идентичности, сочетающей в себе как черты представителей доминантной общности, так и собственные этнокультурные особенности (Giacomarra 2003: 204). В настоящее время среди арбрешской молодежи наблюдается тенденция трансформации этнического «я», которая зародилась в конце XX века после закрытия ряда церковных учреждений, занимавшихся не только образованием, но и приобщением молодого поколения к культурным ценностям своей общины (ПМА 2).

В конце XX века им на смену окончательно пришли государственные образовательные институты, а вместе с ними и новый педагогический контингент, состоявший в основном из сицилийцев или итальянцев, прибывших с материковой части Италии. Проводимая государством политика в отношении этнических меньшинств и их языков также не способствовала укреплению представления арбрешей о ценности собственной этнической принадлежности (Giacomarra 2003). В начале 70-х годов Марио Болоньяри провел опрос среди арбрешей Калабрии на предмет престижности арбрешского языка, согласно данным, полученным в ходе исследования, популярность его использования была очень низкой (Bolognari 1986: 47-48). Многие респонденты высказались о невостребованности родного языка, о трудностях, которые он создает при общении с представителями других этносов, не давая при этом никаких преимуществ. Другие выразили желание не раскрывать своего происхож- 
дения и не использовать арбрешский в повседневной жизни. Наконец, респонденты из третьей группы, состоявшей в основном из мигрантов, отметили, что полностью отказались от родного языка в пользу итальянского (Там же: 49). Данные этого исследования во многом схожи с теми, которые были получены в ходе аналогичного опроса на Сицилии (Giacomarra 2003: 205).

Официальное признание культурного и языкового наследия арбрешских диаспоральных групп началось только после вступления в силу закона 482/1999 о защите исторических языковых меньшинств ${ }^{1}$. Кроме того, многочисленные преобразования последних десятилетий в социальной и экономической сферах в значительной степени способствовали повышению внимания арбрешей к собственной идентичности; вышеупомянутый закон 482 повлиял на расширение сфер использования арбрешского языка (Giacomarra 2003: 203). Однако, по словам информантов, этого недостаточно, чтобы современная молодежь в полной мере могла овладеть родным языком, хотя интерес к нему и возрос в последнее время. В отличие от своих бабушек и дедушек, молодое поколение вовсе не умеет писать по-албански или использует для этого итальянский алфавит. Многие говорят на арбрешском исключительно в кругу семьи, в то время как на работе или учёбе применяют итальянский. К сожалению, на территории Пьяна-дельи-Альбанези не хватает соответствующих научных и образовательных учреждений, которые взяли бы на себя ответственность за конструирование и поддержание арбрешской идентичности (ПМА 2).

В этих условиях в последнее время всё большую значимость стали приобретать такие элементы традиционной культуры, как привязанность к византийскому обряду и этническая одежда. Большинство арбрешей Пьяна-дельи-Альбанези венчаются по византийскому обряду, при этом женщины предпочитают выходить замуж именно в традиционной одежде. «Свадьба становится уникальным событием, поскольку в этот момент албанская идентичность достигает своего триединства, заключенного в языке богослужения, самом обряде и традиционной одежде. Это наивысшая точка проявления национального самосознания, когда арбреш полностью осознает, кем он является» (ПМА 2: Г. Паррино). В этом смысле обряд венчания и весь свадебный цикл играет немаловажную роль в сохранении не только семейных, но в первую очередь культурных ценностей, составляющих этническую специфику арбрешей и формирующих их идентичность.

В Пьяна-дельи-Альбанези исторически сосуществуют приверженцы двух христианских обрядов - византийского и латинского. Несмотря на то, что последних меньшинство, между верующими до сих пор наблюдаются сложные отношения (Parrino 2004). С момента возникновения Итало-албанской церкви на протяжении многих лет

\footnotetext{
${ }^{1}$ После 1989 года в свете автономистских и даже сепаратистских движений в некоторых европейских странах в Италии стала особенно актуальной проблема этнических меньшинств. В этой связи правительством страны было решено издать закон № 482 от 15 декабря 1999 г., получивший название «Нормы относительно защиты исторических и лингвистических меньшинств». Реформа затронула 14 из 20 областей и 30 из 103 провинций и имела целью распространить некоторые особые гарантии на все этнические меньшинства, проживающие на территории Италии. Согласно этому закону, Республика защищает культурное наследие итальянского языка, который объявляется государственным, а также официально признает языки и культуры групп населения, говорящих на албанском, греческом, каталанском, словенском, хорватском, французском, франко-провансальском, фриульском, ладинском, окситанском, сардинском и германских языках (Mотта 2018).
} 
среди арбрешей возникали разногласия в вопросах идентичности и приверженности собственным этнокультурным особенностям. Основанные арбрешской диаспорой церкви изначально принадлежали восточной традиции, однако влияние Римского престола, дискриминация византо-католиков и столкновения между приверженцами разных обрядов привели к тому, что некоторые приходы были переданы латинской церкви, чьи фанатичные прихожане продолжали вести конфессиональную войну с арбрешами византийского обряда (Elli 2017: 305-307). Так, религиозные споры в Палаццо-Адриано и Контесса-Энтеллине завершились только к недавнему времени ${ }^{1}$ В 1990 году был провозглашен новый Кодекс Канонов Восточных Церквей, гарантирующий защиту верующих восточных обрядов. Согласно Кодексу, прихожане восточно-католических церквей должны обращаться за таинствами посвящения и брака только к своим приходам. Если же таинство было совершено в римской церкви без особого на то разрешения, в этом случае оно признаётся недействительным.

К сожалению, мы не располагаем официальной статистикой относительно численности приверженцев латинского обряда, но, согласно сведениям, полученным от информантов, их меньшинство. В отличие от Калабрии, Базиликаты и Абруцци, где в арбрешских поселениях церкви римского обряда были закрыты, в каждой общине, входящей в епархию Пьяна-дельи-Альбанези, есть по одному приходу для латино-католиков (Sirchia 2002). В самой Пьяна-дельи-Альбанези единственной церковью, чей приход был передан католикам латинского обряда, является церковь Св. Вита, в числе ее прихожан есть и албаноязычные верующие, но их не так много (ПМА 2).

Однако несмотря на то, что большинство жителей поселения принадлежит к византийскому обряду, многие из них предпочитают ходить в церковь Св. Вита. Основной причиной является удобство расположения, также есть приверженцы и новомодных

${ }^{1}$ Палаццо-Адриано и Контесса-Энтеллина - арбрешские коммуны, расположенные на территории Сицилии и входящие в состав епархии Пьяна-дельи-Альбанези. До недавнего времени в Палаццо-Адриано наблюдались существенные разногласия между представителями двух обрядов. «Исконно» сицилийское население выступало в защиту латинского обряда, который, по их убеждению, был принят до того, как на данной территории поселились мигранты из Албании. Однако сами арбреши высказывали прямо противоположное мнение, говоря, что первенство принадлежит византийскому обряду.

В Контесса-Энтеллине религиозные споры приобрели более выраженный характер. Несмотря на то, что некоторые приходы итало-албанской церкви были переданы латино-католикам, приверженцы византийского обряда продолжали посещать церковь Мадонна-делла-Фавара, некогда принадлежавшую им, по случаю ежегодного праздника Богородицы. В августе 2009 года священник византийского обряда, Никола Куччиа, вместе с прихожанами своего прихода появился у церкви, чтобы совершить Параклисис - древнюю литургию в честь Девы Марии, как это делал каждый год, но обнаружил, что дверь заперта. Приходской священник римского обряда, дон Марио Белланка, заявил, что, согласно Кодеку канонического права 1983 года, многовековой обычай, на который ссылались византо-католики, был упразднен и теперь «каждый должен молиться в своей церкви».

По словам информантов, прихожане, пришедшие вместе со священником Куччиа, были вынуждены в течение двух недель служить литургию на улице перед кладбищем. Вмешательство мэра и главы полиции не дало положительных результатов, непреклонность латинского священника стала причиной серьезных разногласий между верующими. После того, как жители Контесса-Энтеллины обратились за помощью к Ватикану и епископу Пьяна-дельи-Альбанези, Конгрегацией восточных церквей (орган Святого Престола по проблемам неримских церквей) было принято решение отстранить от работы обоих священников (ПМА 2). 
веяний, таких как проведение литургии на итальянском языке ${ }^{1}$ и других новшеств, как, к примеру, исполнение современных религиозных песен под гитару (ПМА 1). Византийская церковь критикуется за свою устарелость, в частности за греческий язык, который мало кто понимает. Однако не все жители разделяют такую критику, по мнению информантов, её истинной причиной является невежество тех, кто не хочет углубляться в изучение византийского обряда, его языка и смысла священнодействий (ПМА 2: Г. Паррино). Кроме того, такое отношение к собственной истории и традициям воспринимается многими как неуважение к своим предшественникам, боровшимся за право сохранения византийского обряда и создание Итало-албанской церкви. Эти столкновения на почве религиозных разногласий, происходившие в прошлом и продолжающиеся по сей день, стали ключевой причиной этнического противопоставления сицилиец vs арбреш (Giacomarra 2003; Mandalà 2014).

Латинский и византийский обряды образовались в результате видоизменений богословского, смыслового и чинопоследовательного содержания обрядов христианской религии. Латинский обряд (или латинские обряды) - это совокупность литургических ритуалов, сложившихся в первые века нашей эры в Латинской Церкви, для которых характерно употребление латыни в качестве богослужебного языка. Латинский обряд распространился как на территории Римской империи, так и за её пределами, и претерпел немало изменений, а после Великого разделения церквей был унифицирован Католической Церковью и стал единственным приемлемым для богослужения. Чин божественной литургии, или мессы, отличен от чина литургии Византийского обряда в молитвенном содержании евхаристического канона и состоит из начальных обрядов, двух основных частей - Литургии Слова и Евхаристической Литургии, и заключительных обрядов (Католическая энциклопедия 2005; Верзунов 2012).

Византийская литургическая система, разработанная в православном патриархате Константинополя, также была постепенно принята православными патриархатами Александрии, Антиохии и Иерусалима. В ходе исторического развития многие элементы византийского обряда были существенно изменены и стали носить региональные различия. Фактически византийская литургическая система является результатом синтеза константинопольских и палестинских обрядов и традиционно включает в себя евхаристию, таинства: крещение, венчание, миропомазание, елеосвящение, покаяние и рукоположение в священный сан. Все богослужения византийского обряда совершаются в рамках суточного (дневного) круга, седмичного круга и годового круга и собраны в антологиях или литургических книгах, закрепленных традицией и фактически используемых во время службы (Католическая энциклопедия 2002; Тафт 2000: 7).

В евхология ${ }^{2}$, относящихся к позднему периоду византийского правления на территории Южной Италии и Сицилии, приводятся молитвы и обряды патриархатов Александрии, Антиохии и Иерусалима, добавленные к классической константинопольской редакции. Эти элементы появились во времена эмиграции интеллектуальной элиты, «состоявшей из священнослужителей и монахов, которые в VII веке бежали от

\footnotetext{
${ }^{1}$ На II Ватиканском Соборе (1962-1965 гг.), созванном по инициативе папы Иоанна XXIII, была принята Конституция о Божественной Литургии, которая значительно упростила католическое богослужение и разрешила его проведение на национальных языках (Католическая энциклопедия 2002).

${ }^{2}$ Евхологий - православная богослужебная книга, являющаяся соединением «Служебника» с «Требником» (Богословский словарь 1992: 1120).
} 
персов, арабов и монофелитов, а в VIII и IX веках - от иконоборцев» (Паренти 2009: 337). Несмотря на то, что мигранты не были приверженцами византийского обряда, тем не менее, со священнослужителями Константинопольского Патриархата их сближало православие и греческий язык, посредством которого в литургические тексты Южной Италии и Сицилии были добавлены новые элементы (Там же: 338). В результате изменениям подверглись и тексты, касающиеся Таинства Брака.

Благодаря сохранившимся рукописям нам известно, что основные черты константинопольского чинопоследования брака, изложенные в византийских евхологиях, оформились к IX-X векам, однако «уже в VI веке существовало двухчастное чинопоследование, каждая часть которого состояла из двух молитв - основной и главопреклонной» (Пентковский 2016: 125). Под влиянием исторических событий скопированный из классической константинопольской редакции чин венчания также был изменен и дополнен различными молитвами и обрядовыми компонентами не византийского, а именно иерусалимского и александрийского происхождения (Паренти 2009: 335-336). Наличие в южноитальянской традиции таких элементов чинопоследования брака, как «покрытие брачующихся особым мафорием, апостольское и евангельское чтения, пространная редакция неконстантинопольской молитвы брака, неконстантинопольская молитва общей чаши» свидетельствует о влиянии ближневосточных (Палестина, Египет) и итало-романских литургических традиций (Пентковский 2016: 134-135).

Таким образом, чинопоследование брака, совершаемое сегодня в арбрешских церквях, сложилось в рамках византийской литургической традиции и развивалось на протяжении многих веков. До унификации византийской литургии на совершение церковного чинопоследования брака влияли региональные особенности, поэтому чинопоследование может различаться по количеству и набору молитв, по наличию рубрик и их полноте. Специфика чинопоследования брака, использующегося в Южной Италии, заключается в том, что в его основе лежит двухчастное константинопольское чинопоследование, дополненное молитвами и обрядовыми действиями невизантийского происхождения (Пентковский 2016: 139). Также одной из характерных особенностей византийского обряда является совершение Таинства Брака не только на греческом, но и арбрешском языках (ПМА 2).

\section{Роль церкви в конструировании идентичности арбрешей на современном этапе}

Процесс конструирования и поддержания идентичности не зависит исключительно от внешних факторов. Внутри самого сообщества должны действовать силы, способствующие развитию и сохранению этнического самосознания. Степень владения родным языком и включенности в собственную культуру зависит не только от семейного воспитания, но также и от образования, полученного внутри самой диаспоральной группы. Спустя несколько столетий после первых волн переселения арбрешей на территорию Италии, а именно в XVII веке, началось пробуждение культурно-социальной жизни. Активную роль в данном процессе сыграла интеллигенция. В этот исторический период арбрешское духовенство, интеллектуалы и ученые развернули деятельность, направленную на сохранение языка и культуры своего народа. Не только поэты и писатели посредством творчества способствовали 
укреплению арбрешской идентичности. Различные духовные, общественные и политические организации внесли значительный вклад в сбор, исследование и документирование данных и фактов, касающихся исторического прошлого, фольклора, культурных традиций и обычаев албанских переселенцев.

В это же время шло активное сопротивление процессу ассимиляции, выразившееся в борьбе с органами местной власти и доминирующими социальными группами за сохранение византийского обряда Итало-албанской церкви. Открытие на Сицилии большого количества церковных учреждений в то время было обусловлено необходимостью поддержания этнического самосознания арбрешей в условиях включения в итальянскую культуру (Altimari 1986: 8-9).

В настоящее время также наблюдается осознанное сопротивление влиянию чужой культуры, часто связанное с политическими движениями, социальными и культурными организациями, которые транслируют общественное мнение и тем самым участвуют в конструировании и подержании арбрешской идентичности. Православные праздники, отмечающиеся в крупных поселениях, регулярно собирают представителей арбрешской диаспоры с самых отдаленных мест. Частные хозяйства вкладывают часть прибыли в развитие местных культурных центров. Рост и расширение коммуникаций, распространение средств массовой информации также способствуют повышению осведомленности арбрешских меньшинств относительно собственной культуры.

Религиозная составляющая имеет большое значение в жизни арбрешской общины, поскольку церковные мероприятия становятся объединяющим фактором для жителей тех регионов, где православные обряды были утрачены. Различные ассоциации вносят большой вклад в увеличение посещаемости церквей, продвигая инициативы культурной направленности. Например, основанная в Турине в 1972 году ассоциация «Јеta» (алб. 'Жизнь') каждую субботу устраивала различные мероприятия в большом подвале церкви до тех пор, пока он не был объявлен непригодным для использования, после чего два городских ресторана, управляемые арбрешскими семьями, в течение нескольких лет служили местом проведения культурных мероприятий. В 1989 году после конфликта с лидерами ассоциации, община Пьемонта создала Итало-албанский культурно-развлекательный кружок, который действует и по сей день.

Церковь Сан-Микеле-Арканджело является единственным религиозным центром арбрешей Пьемонта, в частности, тех, кто живет за пределами Турина. Тем не менее, арбрешские семьи стараются поддерживать связь с жизнью Церкви и по-прежнему обращаются к ней за крещениями, свадьбами и похоронами. К сожалению, из-за интеграции в латинские приходы и все большего распространения явления смешанных браков существует угроза утраты византийского обряда (в большей степени среди молодежи и в целом среди поколений тех, кто родился в Турине после иммиграции).

На Сицилии епархия Пьяна-дельи-Альбанези также принимает активное участие в приобщении арбрешей к собственной культуре. Для того, чтобы облегчить понимание отдельных частей литургии, церковное сообщество выпускает брошюры с примечаниями по катехизису на греческом, арберешском и итальянском языках. Епархия всячески способствует экуменическому диалогу между представителями языковых и конфессиональных меньшинств, организует встречи с православным духовенством Албании и Греции, однако именно из-за особенностей культурной и 
религиозной самобытности сообщество сохраняет негативное отношение к биритуализму, считая его неправильным способом экуменического подхода между Западом и Востоком.

Кроме того, раз в четыре месяца выходит собственный журнал епархии под названием «Oriente Cristiano» (ит. 'Христианский восток'), все номера которого имеются в свободном доступе на сайте редакции ${ }^{1}$. В журнале освящается ряд вопросов, связанных с историей религии, церковными деятелями, христианскими праздниками, важными мировыми событиями, а также публикуются фотографии икон, представляющих культурную ценность, и комментарии к ним специалистов в области истории искусств.

Однако, по словам информантов, поселению не хватает женских монастырей, где воспитывались бы монахини Итало-албанской церкви. В качестве иллюстрации приведем цитату из нарратива Г. Паррино (арбреш, 1990 г.р., Пьяна-дельи-Альбанези):

«Нашей иеркви очень не хватает монахинь. Девушки из Пьяна-дельи-Альбанези, желавшие стать монахинями, были вынуждены переехать в другие поселения и воспитываться при латинских монастырях.» (ПМА 2: Паррино).

Приходская жизнь Итало-албанской церкви находит активное выражение в ряде туристических поездок, совершающихся не только в культурно-развлекательных, но и религиозных целях, таких как посещение аббатств и церквей. В этих случаях у прихода есть возможность рассказать о византийских обрядах другим посетителям паломнических центров. Кроме того, многие приходы самостоятельно печатают собственные периодические издания, где публикуются статьи, посвященные восточному обряду, византийскому искусству и обзору литературы на различные богословские и исторические темы. Церковная публицистика стремится охватить все аспекты духовной и светской жизни арбрешского сообщества, и поэтому является богатым источником культурных данных, а также необходимым связующим звеном между жителями разных поселений и регионов.

Среди аспектов, которым уделяется особое внимание в церковно-приходской литературе, можно отметить общую историю происхождения арбрешей, этапы переселения на территорию Италии, сравнения с другими этническими и языковыми меньшинствами, биографические заметки известных албанцев, статьи об албанском языке и литературе, общие новости арбрешской общины, такие произведения фольклора, как песни, стихи, сказки, легенды, а также политико-исторические обзоры, посвященные актуальной ситуации в Албании и Косово.

Проблема сохранения самобытности арбрешей и укрепления чувства их этнической принадлежности породила насыщенную культурную жизнь. Итало-албанские приходы в течение долгих лет накапливали информацию об истории, традициях и обычаях своей общины, укрепляли внешние и внутренние связи, благодаря чему между представителями арбрешской диаспоры возникло чувство внутренней сплоченности. Рост и развитие коммуникации, усовершенствование средств массовой информации также воздействуют на современную культуру арбрешских диаспоральных групп. Процессы модернизации способствуют распространению информации и повышению осведомленности языковых меньшинств, формируя таким образом представление об их этнической принадлежности. По словам информантов, в настоящее время идентичность начинает конструироваться также посредством

\footnotetext{
${ }^{1}$ Quadrimestrale dell'eparchia di Piana degli Albanesi: http://www.orientecristianopiana.it.
} 
интернет-ресурсов. Религиозные сообщества, идя в ногу со временем, создают собственные сайты, где размещают актуальную информацию, касающуюся социокультурной жизни итало-албанской церкви (ПМА 2).

Однако иммигранты последних лет, прибывающие из Албании, оказываются в совершенно иной ситуации, нежели в прошлом. Политика уничтожения религии, проводимая албанскими коммунистами в XX веке, способствовала развитию различных форм религиозного индифферентизма, что в настоящее время резко контрастирует с привязанностью арбрешей к своей вере (Смирнова 2003: 370). Кроме того, для албанцев, только что прибывших в Италию, арбрешский язык часто создает препятствия к пониманию не только бытовой речи, но и текста многих религиозных обрядов. Отказываясь принять обычаи арбрешей, новое население рискует потерять поддержку местных сообществ. В этой связи часть арбрешской диаспоральной группы считает необходимой адаптировать те черты собственной культуры, которые сегодня могут показаться архаичными и незначительными для новых иммигрантов. Другая же часть выступает против подобных изменений и стремится к сохранению исконных самобытных черт арбрешской культуры (ПМА 2).

Таким образом, сегодня Итало-албанская церковь с активной позицией духовенства, как и в прошлом, выполняет роль одного из самых сложных и значимых социальных и культурных институтов. На протяжении веков его представители организовывали и проводили мероприятия, направленные на культивирование этнической специфики арбрешей и поддержание их идентичности. Итало-албанская церковь высоко ценится своими прихожанами, и все больше воспринимается как религиозный, социальный и культурный институт, ответственный за сохранение ценностей религиозной культуры, тесно связанной с социальной средой в целом.

\section{Основные выводы}

Длительное проживание в изоляции от источника традиции и деятельность местных интеллектуалов, выступавшей за развитие образования и сохранение этнического самосознания, способствовало тому, что арбрешские общины на протяжении более пяти веков сохраняли свою идентичность, демонстрируя жизнеспособность своей традиционной культуры. Однако экономическое развитие и глобализация направляют людей на переосмысление своей идентичности в личностном и общественном плане. Разнообразные социокультурные процессы находят свое отражение в соответствующих изменениях в сфере декларирования этнической принадлежности. Быстрое развитие коммуникации, растущая мобильность людей влияют на традиционные модели поведения, наблюдается ослабление социальных связей, размывание этнических границ и снижение ценностных ориентиров.

Мультикультурный характер современных обществ способствовал тому, что самосознание представителей арбрешской общины существенно видоизменилось за последние десятилетия, несмотря на общий язык и историческую память. В процессе адаптации к новым условиям, а также культурного взаимодействия с сицилийцами, начался процесс формирования смешанной идентичности, сочетающей в себе как собственные этнокультурные особенности, так и черты представителей доминантной общности. 
В этих условиях осмысление своего этнического «я» все чаще происходит во время важных религиозных и исторических праздников, а также семейных мероприятий, когда представители того или иного этноса либо его диаспоральной группы начинают позиционировать свои исторические корни и значительное языковое, религиозное и традиционное наследие, которые на протяжении веков они сохраняли. В этом смысле византийский обряд венчания становится ключевым маркером арбрешской идентичности, так как объединяет в себе три главные составляющие: язык, ритуал и костюм. Это целостное этнокультурное явление, продолжающее жить в современном социокультурном пространстве и выполняющее важную этнодифференцирующую функцию для арбрешей.

Византийский обряд по-прежнему остаётся наиболее устойчивым к трансформации, поскольку местное духовенство отвечает за сохранность религиозной культуры, тесно связанной с социальной средой в целом, а также направляет свою деятельность на культивирование и сохранение арбрешской идентичности. Итало-албанская церковь представляет значительный институт, который движется к новым формам организации или изменяет роль существующих, чтобы реагировать на вызовы современного общества. Местное духовенство отвечает за сохранность религиозной культуры, которая тесно интегрирована в социальную среду, а также направляет свою деятельность на культивирование и сохранение арбрешской идентичности.

\section{Источники и материалы}

Католическая 2002 - Католическая Энциклопедия. Том 1. Буквы А-3. Москва, 2002. Доступ: https://rus-katolic-enc.slovaronline.com/ (дата обращения 30.05.2020)

Католическая 2005 - Католическая Энциклопедия. Том 2. Буквы И-Л. Москва, 2005. Доступ: https://rus-katolic-enc.slovaronline.com/ (дата обращения 30.05.2020)

Мотта 2018 - Мотта Дж. Этнические меньшинства и регионализм в Италии. Вестник Европы. 2018. № 50. Доступ: https://magazines.gorky.media/vestnik/2018/50 (дата обращения: 29.08.2020).

Полный православный 1992 - Полный православный богословский энциклопедический словарь. Том 1. Москва: Возрождение, 1992. 1-1120 стб. 1121-2464 стб. pdf.

ПМА 1 - Полевые материалы автора. Экспедиция в с. Пьяна-дельи-Альбанези, провинция Палермо, (Сицилия). 2016-2017 гг. Полевая тетрадь. (информанты - С. Скиро 1988 г. р., Г. Паррино 1990 г.р., Дж. Скиро 1970 г. р. и др.).

ПМА 2 - Полевые материалы автора. Удаленный опрос информантов из с. Пьяна-дельи-Альбанези, провинция Палермо, (Сицилия). 2019-2020 гг. (информант - Г. Паррино 1990 г.р.).

Научная литература

Арш Г.Л., Иванова Ю.В., Колпакова О.А., Смирнова Н.Д. Краткая история Албании: С древнейших времен до наших дней / под ред. Г.Л. Арша. М.: Наука, 1992. 512 с.

Иващенко А. Состояние христианской церкви и христианского населения Сицилии под властью мусульман // Духовный вестник. Том XVI. Харьков 1867. Pdf

Норвич Дж. История Сицилии. М.: Издательство АСТ, 2018. 384 с.

Норвич Дж. Нормандцы в Сицилии. Второе нормандское завоевание. 1016-1130. М.: Центрполиграф, 2015. $386 \mathrm{c.}$

Паренти С. К вопросу об истории локальных традиций чинов таинств по византийскому Евхологию // Материалы V Международной Богословской Конференции Русской Православной Церкви «Православное учение о церковных таинствах. Том III: Брак. Покаяние. Елеосвящение. Таинства и тайнодействия (Москва 13-16 ноября 2007)» / науч. ред.: Желтов М., Москва: Синодальная библейско-богословская комиссия, 2009. С. 332-346. 
Паче Б. Варвары и византийцы на Сицилии // Сицилийский исторический архив, Новая серия, XXXV / Пер. с итал. В. Г. Изосина, Палермо 1920. С. 33-80, 293-324.

Пентковский А.M. Рецепция константинопольского чинопоследования брака в Южной Италии, на Балканах и на Руси в X-XV вв. // Россия - Италия: этико-культурные ценности в истории / ред.: М.Г. Талалай. Санкт-Петербург: Алетейя, 2016. С. 125 -139.

Роберсон Р. Восточные христианские церкви // Церковно-исторический справочник. Санкт-Петербург: Высшая религиозно-философская школа, 1999. 196 с.

Смирнова Н.Д. История Албании в ХХ веке // Институт всеобщей истории. М.: Наука, 2003. $431 \mathrm{c}$.

Taфm Р.Ф. Византийский церковный обряд. Краткий очерк. Санкт-Петербург: Алетейя, 2000. $111 \mathrm{c}$.

Altimari $F$. Le comunità albanesi e la legge di tutela delle minoranze linguistiche storiche: alcune buone esperienze realizzate in ambito istituzionale // Atti del convegno «Politiche linguistiche dell'Unione Europea», Messina, 1 dicembre, 2006 / A cura di Abbate L., Edizioni dell'Orso: Alessandria, 2008. Pp. 43-51.

Altimari F. Mësimdhënia e gjuhës minoritare në realitetin gjuhësor arbëresh. Kerkime universitare, 2002, N. 5. Pp. 17-27.

Elli A. Breve storia delle Chiese cattoliche orientali (II Ed). Terra Santa, 2017, 400 p.

Emmanuele D. Arberia: storia, cultura e folklore. Castrovillari, 1988, 260 p.

Fratelli Tramuto e Ciofalo. La Celebrazione del Matrimonio nel Rito Greco. Hora e t’Arbëreshëvet, 1971.

Giacomarra M. Condizioni di minoranza oggi. Gli albanesi di Sicilia fra etnicismi e globalizazione. Palermo: Miror, 2003. Pp. 84-120.

Guagliardi D. La comunità albanese di Sicilia // La Diversità Arbëreshe. Vol. I: La formazione, la storia, l'insediamento. Cosenza: Falco Editore, 2004. 368 p.

Manali P. Hora e Arbëreshëvet. Piana degli Albanesi. Palermo: Comune di Piana degli Albanesi, 2005.

Mandalà M. Arbëreshët e fillimet e nacionalizmit shqiptar // In Meta B. (a cura di), 110 vjet Pavarësi. Aktet e Konferencës Shkencore Ndërkombëtare (Tiranë, më 26-27 nëntor 2012). Tirana: Qendra e Studimeve Albanologjike. Instituti i Historisë, 2014. Pp. 101-119.

Mandalà M. L'emigrazione albanese in Italia tra il XIV secolo e la prima metà del XV // In M. Brunetti (a cura di), Il passato pesa sul presente. Cosenza, 2011. Pp. 73-99.

Mastroberti F. Le colonie albanesi nel Regno di Napoli tra storia e storiografia. Bari: Università degli studi di Bari. Cacucci editore 2008, Pp. 241-251.

Sirchia V.M. Mistagogia dei misteri sacrimentali nella Chiesa bizantina // Quaderni di Oriente Cristiano. Studi 12. Eparchia di Piana degli Albanesi, 2002. 53 p.

Tagarelli $A$. Studio antropologico della comunità arbëreshe della provincia di Torino / A cura di Antonio Tagarelli. Istituto di Scienze Neurologiche Consiglio Nazionale delle Ricerche Mangone (Cosenza), 2003. 134 p.

Suloeva, Marina A.

\section{The role of the Italian-Albanian Church and the function of the Byzantine Rite in constructing the identity of the Arbresh of Sicily}

DOI: $10.33876 / 2311-0546 / 2021-54-2 / 44-60$

The article is devoted to the Byzantine rite as one of the key markers for the development of the Arbresh diaspora identity in Sicily. Rapid development of communications and increasing mobility of population lead to a weakening of social ties, blurring of ethnic borders and a decrease in values. The fear of losing the identity has given rise to a rich cultural life of the Arbresh. Over the years, parishes of the Italo-Albanian Church have been accumulating 
information about the history, traditions and customs of their community, strengthening external and internal ties, which inspired a feeling of internal cohesion inside the Arbresh diaspora. The Byzantine rite stays most resistant to transformation, since the local clergy are responsible for the preservation of the religious culture, which is closely related to the social environment as a whole, and directs its activities towards the cultivation and preservation of the Arbresh identity. The Italo-Albanian Church represents a significant institution that moves towards new forms of organization or changes the role of existing ones in order to respond to the challenges of modern society. The Italo-Albanian Church is highly valued by its parishioners and is increasingly perceived as a religious, social and cultural institution responsible for preserving the values of the religious culture, which is closely related to the social environment as a whole.

Keywords: Arbresh diaspora, Piana degli Albanesi, the Byzantine rite, identity, the ItaloAlbanian Catholic Church, traditional culture

For Citation: Suloeva, M.A. 2021. The role of the Italian-Albanian Church and the function of the Byzantine Rite in constructing the identity of the Arbresh of Sicily. Herald of Anthropology (Vestnik Antropologii) 2: 44-60.

\section{Author Info:}

Suloeva, Marina A. - PhD student, Peter the Great Museum of Anthropology and Ethnography (Saint Petersburg, Russia). E- mail: suloevamarina@yandex.ru

\section{References}

Arsh, G. L., and Yu.V. Ivanova, O.A. Kolpakova, N.D. Smirnova. 1992. Kratkaia istoriia Albanii: $S$ drevneishikh vremen do nashikh dnei [A Brief History of Albania: From Ancient Times to the Present], edited by G. L. Arsh, Moscow: Nauka.

Norvich, Dzh. 2015. Normandtsy v Sitsilii. Vtoroe normandskoe zavoevanie. 1016-1130 [The Normans in Sicily. Second Norman conquest. 1016-1130]. Moskow: Tsentrpoligraf.

Norvich, Dzh. 2018. Istoriia Sitsilii [The history of Sicily]. Moskow: Izdatel'stvo AST.

Ivashchenko, A. 1867. Sostoianie khristianskoi tserkvi i khristianskogo naseleniia Sitsilii pod vlast'iu musul'man [The state of the Christian church and the Christian population of Sicily under Muslim rule]. Dukhovnyi vestnik. Vol. XVI. Khar'kov.

Parenti, S. 2009. K voprosu ob istorii lokal'nykh traditsii chinov tainstv po vizantiiskomu Evkhologiiu [On the question of the history of local traditions of the rites of the sacraments according to the Byzantine Euchology]. Materialy V Mezhdunarodnoi Bogoslovskoi Konferentsii Russkoi Pravoslavnoi Tserkvi. Moskva 13-16 noiabria, 2007 [The materials of V International theological conference of the Russian Orthodox Church. Moskow, November 13-16, 2007)] Zheltov M. (ed). Moskow: Sinodal'naia bibleisko-bogoslovskaia komissiia: Pp. 332-346.

Pache, B. 1920. Varvary i vizantiitsy na Sitsilii [Barbarians and Byzantines in Sicily]. Sitsiliiskii istoricheskii arkhiv, Novaia seriia, XXXV, translated by V. G. Izosina, 33-80, 293-324. Palermo

Pentkovskii, A.M. 2016. Retseptsiia konstantinopol'skogo chinoposledovaniia braka v Iuzhnoi Italii, na Balkanakh i na Rusi v X-XV vv. [Reception of the Constantinople marriage ceremony in southern Italy, the Balkans and Russia in the X-XV centuries]. In Rossiia - Italiia: etikokul 'turnye tsennosti $v$ istorii [Russia-Italy: ethical and cultural values in history], edited by M.G. Talalai, 125-139. Saint-Peterburg: Aleteiia.

Roberson, R. 1999. Vostochnye khristianskie tserkvi [Eastern Christian churches]. Tserkovno-istoricheskii spravochnik. Saint-Peterburg: Vysshaia religiozno-filosofskaia shkola. 
Smirnova, N.D. 2003. Istoriia Albanii v XX veke [The history of Albania in the XX century]. Institut vseobshchei istorii. Moskow: Nauka.

Taft, R.F. 2000. Vizantiiskii tserkovnyi obriad. Kratkii ocherk [Byzantine Church rite. Brief sketch]. Sankt-Peterburg: Aleteiia.

Altimari, F. 2008. Le comunità albanesi e la legge di tutela delle minoranze linguistiche storiche: alcune buone esperienze realizzate in ambito istituzionale [Albanian communities and the law for the protection of historical linguistic minorities: some good experiences achieved in the institutional context] In Atti del convegno «Politiche linguistiche dell'Unione Europea», Messina, 1 dicembre, 2006. A cura di Abbate L., Edizioni dell'Orso, 43-51. Alessandria.

Altimari, F. 2002. Mësimdhënia e gjuhës minoritare në realitetin gjuhësor arbëresh [Teaching minority language in the linguistic reality of the Arbresh]. Kerkime universitare 5: 17-27.

Elli, A. 2017. Breve storia delle Chiese cattoliche orientali (Vol. II) [A brief history of the Eastern Catholic Churches]. Terra Santa.

Emmanuele, D. 1988. Arberia: storia, cultura e folklor [Arberia: history, culture and folklore]. Castrovillari.

Fratelli Tramuto e Ciofalo. 1971. La Celebrazione del Matrimonio nel Rito Greco [The Celebration of Marriage in the Greek Rite]. Hora e t'Arbëreshëvet.

Giacomarra, M. 2003. Condizioni di minoranza oggi. Gli albanesi di Sicilia fra etnicismi e globalizazione [Minority conditions today. The Albanians of Sicily between ethnicism and globalization], 84-120. Palermo: Miror.

Guagliardi, D. 2004. La comunità albanese di Sicilia [The Albanian community of Sicily]. La Diversità Arbëreshe. Vol. I: La formazione, la storia, l insediamento. Cosenza: Falco Editore.

Manali, P. 2005. Hora e Arbëreshëvet. Piana degli Albanesi [Piana degli Albanesi]. Palermo: Comune di Piana degli Albanesi.

Mandalà, M. 2014. Arbëreshët e fillimet e nacionalizmit shqiptar [The Arbresh and the beginnings of Albanian nationalism] In Meta B. (a cura di), 110 vjet Pavarësi. Aktet e Konferencës Shkencore Ndërkombëtare (Tiranë, më 26-27 nëntor 2012), 101-119. Tirana: Qendra e Studimeve Albanologjike. Instituti i Historisë.

Mandalà, M. 2011. L'emigrazione albanese in Italia tra il XIV secolo e la prima metà del XV [The Albanian emigration to Italy between the fourteenth century and the first half of the fifteenth]. In M. Brunetti (a cura di), Il passato pesa sul presente, 73-99. Cosenza.

Mastroberti. F. 2008. Le colonie albanesi nel Regno di Napoli tra storia e storiografia [The Albanian colonies in the Kingdom of Naples between history and historiography], 241-251. Bari: Università degli studi di Bari. Cacucci editore.

Sirchia, V.M. 2002 Mistagogia dei misteri sacrimentali nella Chiesa bizantina [Mystagogy of the sacramental mysteries of the Byzantine Church]. Quaderni di Oriente Cristiano. Studi 12. Eparchia di Piana degli Albanesi.

Tagarelli, A. 2003. Studio antropologico della comunità arbëreshe della provincia di Torino [Anthropological study of the arbresh community of the province of Turin] / A cura di Antonio Tagarelli. Istituto di Scienze Neurologiche Consiglio Nazionale delle Ricerche Mangone (Cosenza). 